Available online at GSC Online Press Directory

GSC Advanced Research and Reviews e-ISSN: 2582-4597, CODEN (USA): GARRC2

Journal homepage: https://www.gsconlinepress.com/journals/gscarr

(RESEARCH ARTICLE)

\title{
COVID-19 and food insecurity in Cameroon
}

Foka-Nkwenti Christopher, Nguendo Yongsi H. Blaise *, Noela Ambe Mpeh and Nganou-Mouafo Madelle

${ }^{1}$ Department of Geography - University of Douala, Cameroon.

${ }^{2}$ Institute for Population Studies (IFORD) - University of Yaoundé II, Cameroon.

${ }^{3}$ Department of Geography - University of Douala, Cameroon.

${ }^{4}$ Department of Geography - University of Douala, Cameroon.

Publication history: Received on 11 November 2020; revised on 18 November 2020; accepted on 20 November 2020

Article DOI: https://doi.org/10.30574/gscarr.2020.5.2.0104

\begin{abstract}
Background: more than half of the world's population is currently facing health crisis. As a result, millions of businesses have had to shutdown either temporarily or permanently. With COVID-19 and its economic fallout, now spreading in the poorest regions of the world, many more people will become poor and food-insecure. Increased food insecurity may act as a multiplier for the epidemic due to its negative health effects and increased in national starvation. The impacts of COVID-19 are particularly strong for people in the lower tail of the food insecurity distribution. In the current context, the effects of food insecurity could be made worse as a result of the general rise of food stuff prices.
\end{abstract}

Objective: in this paper, we will investigate the interaction between COVID-19 and the drop in the food price leading to food insecurity in Cameroon.

Data collection: rapid phone survey across the national territory (Cameroon) confirm(s) the widespread impact of COVID-19 on household and food insecurity. Data collected in urban markets shows that main cities are highly affected by the covid-19 crises. Data retrieved was linked and processed in data editing software (Microsoft Office) for the production of results in text and tabular format.

Result: as the coronavirus crisis unfolds, disruptions in domestic food supply chains and loss of incomes and remittances are creating strong tensions and food insecurity in Cameroon. Despite stable food prices of certain goods, most cities are experiencing varying levels of food price inflation at the retail level, reflecting supply disruptions due to COVID-19. Rising food prices have a greater impact in low and middle income consumers since a larger share of their income is spent on food.

Keywords: Health Crisis; COVID-19; Food Insecurity; Epidemic; Prices; Cameroon

\section{Introduction}

Access to food is now more than ever an issue of interest [1]. In any society where people are hungry or where many children are malnourished, food ought to be the major concern for people working in health [2]. Poor nutrition due to lack of food leads to bodily weakness which in turn leads to greater susceptibility to illness and death. Thus poor nutrition as caused by hunger and poverty is probably the major cause for concern of amongst poor people and probably the major cause of death today in young children [3]. Rising food prices can have a devastating effect on the health of

\footnotetext{
${ }^{*}$ Corresponding author: Nguendo Yongsi H. Blaise

Institute for Population Studies (IFORD) - University of Yaoundé II,

(Cameroon).

Copyright $(2020$ Author(s) retain the copyright of this article. This article is published under the terms of the Creative Commons Attribution Liscense 4.0.
} 
poor households by making it more difficult for them to afford basic food [4]. The effect of prices on food insecurity is important in the context of recent research $[5,6,7,8]$.

Higher food prices lead poor people to limit their food consumption and adjust to an increasingly unbalanced diet, which has a harmful effect on health in the short-term (hunger) and long term (food insecurity) [4]. The Excessive Food Price Variability Early Warning System is a tool of food security. High prices of food stuff are the ultimate signal that demand is outstripping supply, that there is simply not enough food to go around [9]. Food prices strongly influence the livelihoods and food choices of farmers, traders, processors, and consumers. When markets are tight, prices are sensitive to shocks such as a bad harvest or in today's context referred to as supply disruptions caused by COVID-19. For the poor who spend most of their income on food, any food price increase may put their food security at risk. When the world food crisis exploded in 2007-2008, international prices of all major food commodities (especially wheat, rice, soya and maize) reached their highest level in nearly 30 years, pushing the number of people living in hunger to one billion, and compromising the human right to adequate food and nutrition of many more [1, 9]. In 2008, the "crisis" which many have described as a multifold food, fuel, finance, climate and even a human rights crisis brought the cracks of an unsustainable and broken food system into view forcing policy makers to acknowledge its failures [1].

According to Arif Husain (chief economist at the United Nations World Food Program) the pandemic has doubled the number of people who are acutely food insecure from 135 million people in 2019 to 270 million [10]. He said food aid will be at a record, hopefully reaching some 138 million people globally with food and cash assistance, topping a previous peak. "Unless immediate action is taken, it is increasingly clear that there is an impending global food emergency that could have long-term impacts on hundreds of millions of children and adults," he said. "We need to act now to avoid the worst impacts of our efforts to control the pandemic [10]." To this end, it awakens states and urges them to focus on ways to make food systems resilient in order to ensure their security [11]. To date, the crisis is viewed primarily from a public health perspective (as it should) [12]. It is only gradually that national strategies, working groups and funds are focusing their attention on the economic fallout and impact on food security in Africa. As in the rest of the world, there are new signs in Africa of the negative impact of covid-19 on the agrifood system. These difficulties include difficulties in transporting food from rural to urban areas, closing of markets, rising food prices, loss of livelihoods, flight of workers to rural areas and increased use of social safety nets. In many countries, covid-19 puts severely test agrifood systems which present structural weaknesses. This crisis caused a decline in economic productivity due to the many lost in jobs, collapse of sectors of activity directly affected, such as catering, the increasingly growing vulnerability of poor households and the reduction in purchasing power. On the continent, administrations fear the collapse of food systems fostered by the implementation of restriction and containment measures [13]. In West and Central Africa, nearly 50,000,000 people could reach the threshold of food insecurity due to the health crisis [14]. In addition, demand was constrained by uncertainties which strongly affected the purchasing power of households. In Cameroon, social gaps created by the pandemic are still wide which has affected the local and international supply chains.

A food crisis is worsening around the world as the coronavirus pandemic drags on. The crisis linked to the rise in prices has increased the number of people living below the poverty line. Indeed, while the food situation of poor households has deteriorated further, that of households already living in precarious situations has also weakened. However, this study emanates from the observation that in Cameroon, the occurrence of the pandemic has made the prices of certain foodstuffs unstable while weakening all economic sectors. This crisis affects all components of the food system, namely production, marketing, distribution and consumption. However, this can have long-term consequences for household food security. Therefore, it poses as a problem the influence of Covid-19 on household food security in Cameroon. This food insecurity that the population risks is characterized by the unavailability, inaccessibility, instability and use of food resources. This work aims to show the influence of the health crisis on food security while justifying the food crisis.

\section{Methods}

This analysis is based on qualitative data collected through academic work and various tasks. The data was collected during and after the lockdown period in Cameroon from March 30 to September 30 . A rapid phone survey of 487 households was conducted across national territory to measure the weight of the impact of covid-19 on the prices of foodstuffs on the national territory. Corresponding prices of everyday consumer goods were obtained in the urban markets of Douala, Yaoundé, Bafoussam Bertoua and Bamenda. A structured questionnaire of approximately 10 questions was administered to the household regarding changes in the evolution of the pandemic and the national food situation. Other relevant data was obtained from local media houses. The data obtained from this sampling frame were noted and transferred into Microsoft software for data processing and production of results in text and tabular form. The language used during data collection was French and English. From an ethical standpoint, the study team insisted on data quality control to ensure the reliability of decisions. Finally, the analysis was based on the contextualization and 
interpretation of the explanatory model of (Beaud and Weber, 2010) [15]. Since the facts that result from the data collected must be interpreted with caution, the sample size obtained is smaller compared to the representation of the national sample, resulting in a weakness of our sample. The elements used to measure food insecurity were taken from the INSPQ (Institut National De Sante Publique Du Quebec) model based on food prices before, during and after crises.

\subsection{Covid-19 and drop in food prices in Cameroun}

Market prices of food stuffs before, during and after the confinement period in Douala fluctuated and while some prices increased, others dropped drastically. On one hand, we can say the covid-19 pandemic created an atmosphere for food security as we can notice the price drop of some essential food stuffs. In order to verify this assertion, we are going to investigate the availability, accessibility, affordability and safety of food during the confinement period.

Table 1 showing the drop in food prices during the confinement period in Cameroon

\begin{tabular}{|c|c|c|c|c|}
\hline Food Category & Foodstuffs & $\begin{array}{l}\text { Price range before } \\
\text { confinement in } \\
(F C F A)\end{array}$ & $\begin{array}{l}\text { Price range during } \\
\text { confinement in francs } \\
(F C F A)\end{array}$ & $\begin{array}{l}\text { Price range after } \\
\text { confinement in francs } \\
(F C F A)\end{array}$ \\
\hline \multirow{3}{*}{$\begin{array}{l}\text { Vegetables and } \\
\text { fruits }\end{array}$} & Vegetables & 250-500 per bundle & 100-250 per bundle & 200-500 per bundle \\
\hline & Tomatoes & 4000-5000 per basket & $1500-2000$ per basket & $13000-15000$ per basket \\
\hline & Onions & $25-200$ per onion & $10-150$ per onion & $50-200$ per onion \\
\hline \multirow{2}{*}{ Lipids } & Eggs & $1800-2300$ per tray & $1500-2200$ per tray & $2100-2500$ per tray \\
\hline & Groundnut oil & 1500 per 1.5 liter & 1250 per 1.5 liter & 1350 per 1.5 liter \\
\hline \multirow[t]{2}{*}{ Fish and meat } & $\begin{array}{l}\text { Dry fish } \\
\text { (Mbonga) }\end{array}$ & 13 pieces for 500 & 15 pieces for 500 & 13 pieces for 500 \\
\hline & Chicken & $2200-10000$ & $1800-7500$ & $2500-15000$ \\
\hline \multirow{2}{*}{$\begin{array}{l}\text { Basic food } \\
\text { products }\end{array}$} & Egussi & 200 per cup & 125 per cup & 125 per cup \\
\hline & Red beans & 175 per cup & 150 per cup & 200 per cup \\
\hline
\end{tabular}

Due to the closure of borders, export was made difficult for whole sale vendors and producers hence they had to depend solely on local market which was a great disadvantage for them. In as much as this situation was a huge loss for vendors off different goods, it favored the population and increased the availability of food stuffs and since supply exceeded demand, food was not only available but affordable too. Vendors in order to lighten the burden of their huge loss moved towards consumers thus facilitated their access to food. Due to the strict hygiene measures and close monitoring, safety of food stuffs were enhanced as market vendors struggled to win the approval of consumers through extra efforts to ensure the safety of what they sold.

This is the case with tomatoes. Farmers in Cameroon are hard hit following the drastic drop in the prices of tomatoes. The pandemic that caused borders with neighboring countries to be closed, has heavily affected the sales. Countries like Nigeria. Equatorial Guinea, Gabon, Chad, Congo and Central African Republic that were lucrative markets for the over 877937 tons of tomatoes produced annually, have seen the borders blocked from the importation of goods. A basket of tomatoes that used to cost between 4000FCFA and 5000FCFA during peak harvest season has dropped to a price range of 1000FCFA and 2000FCFA. Many of the tomatoes dealers explained "we are forced to hire vehicles to move from door to door, market to market to solicit consumers to buy at a give-away price of $1500 \mathrm{frs}$ to $2000 \mathrm{frs}$ ". This has encouraged many households to buy tomatoes in bulk. Some grinding and storing in refrigerators ahead of out of season consumption. This door to door sales has also killed and hampered the activities of retailers. They hardly make quick business these days because consumers go for tomatoes in baskets [16]. 
Also, we had a price drop in vegetables as vendors struggled to sell off even in quarters to prevent them from getting rotten in case markets were to be closed. Again, in the agro-pastoral sector, some producers especially of tomatoes, fowls, pork, and fish have not recovered from the enormous loss. Faced with the restrictions imposed, markets experienced a drastic loss with unimaginable repercussions on the supply chain [17]. Apart from tomatoes and vegetables, we have onions, groundnut oil, dry fish, chicken and eggs.

It should be noted, however, that the drop in prices could not only be attributed to the impact of the covid-19 pandemic and confinement, but also to seasonal changes. While some food items like onions were cheap during the lockdown period that was due to its season. However, some consumers may be buying onions at below market prices due to the frustration of some local vendors by the Covid-19 crises.

\subsection{Covid-19 and increase in food prices in Cameroun}

The current food context is marked by instability in food costs caused by a disruption in local supply chains that has resulted in an increase in the prices of certain foodstuffs [18]. Poor households, mostly working in the informal sector, have seen their activities come to an end because of the restriction measures, are more affected by this food insecurity because being without income could not have access to quality food. As confinement was an uncertainty, the number of meals is therefore reduced due to the presence of all household members throughout the days at home, thereby further complicating the diet and its frequencies.

Table 2 showing the increase in the prices of common food stuff during Covid-19 pandemic in Cameron.

\begin{tabular}{|c|c|c|c|c|}
\hline $\begin{array}{l}\text { Food } \\
\text { Category }\end{array}$ & Food Stuffs & $\begin{array}{lr}\text { Price range } & \text { before } \\
\text { confinement } & \text { in } \\
\text { francs }(F C F A) & \end{array}$ & $\begin{array}{l}\text { Price range during } \\
\text { confinement in } \\
\text { francs }(F C F A)\end{array}$ & $\begin{array}{l}\text { Price range } \text { after } \\
\text { confinement in } \\
\text { francs }(F C F A)\end{array}$ \\
\hline \multirow[t]{2}{*}{$\begin{array}{l}\text { Cereals and } \\
\text { wheat }\end{array}$} & Rice & 17000-21000 per bag & $\begin{array}{l}18000-22000 \text { per } \\
\text { bag }\end{array}$ & $\begin{array}{l}18500-24000 \text { per } \\
\text { bag }\end{array}$ \\
\hline & Spaghetti & 6100 per cartoon & 6200 per cartoon & 6200 per cartoon \\
\hline \multirow{5}{*}{$\begin{array}{l}\text { Vegetables } \\
\text { and fruits }\end{array}$} & Lime & 3 lime for 100 & 3 lime for 500 & 3 lime for 150 \\
\hline & Lemon & 100 per piece & 300 per piece & 150 per piece \\
\hline & Aloe vera & 100 per piece & 150-250 per piece & 100 per piece \\
\hline & Garlics & 3 piles for 500 & 2 piles for 500 & 3 piles for 500 \\
\hline & Ginger & 100 per pile & 300-500 per pile & 100 per pile \\
\hline lipids & Red oil & 450 per liter & 500 per liter & 600 per liter \\
\hline \multirow{8}{*}{$\begin{array}{l}\text { Basic food } \\
\text { products }\end{array}$} & Banana & 6 fingers for 100 & 6 fingers for 200 & 6 fingers for 200 \\
\hline & Cocoyam & 500 per pile & 500 per pile & 500 per pile \\
\hline & Cabbage & 200-500 per piece & 300-500 per piece & 300-700 per piece \\
\hline & Irish potatoes & 600 per 5 liter bucket & $\begin{array}{l}650 \text { per } 5 \text { liter } \\
\text { bucket }\end{array}$ & $\begin{array}{l}650 \text { per } 5 \text { liter } \\
\text { bucket }\end{array}$ \\
\hline & Black beans & 100 per cup & 150 per cup & 200 per cup \\
\hline & White beans & 150 per cup & 150 per cup & 200 per cup \\
\hline & Groundnuts & $100-150$ per cup & $125-175$ per cup & $125-175$ per cup \\
\hline & Maize & $200-250$ per cup & $200-250$ per cup & 275-300 per cup \\
\hline
\end{tabular}

In addition, agricultural production is unstable due to the instability of all sectors, from production to consumption.

On the other hand, we can also say that the covid-19 pandemic has created an atmosphere of food insecurity. The availability, accessibility, affordability and safety of food were affected during this period. Measures taken to prevent the spread of COVID-19, such as restrictions on the movement of people and vehicles, closure of borders to individuals 
and restrictions on business activities, have had a negative impact on poor households, in particular those in urban areas, who depend on income from informal employment and petty trading. In times of crisis, Cameroonians have witnessed a general increase in the prices of basic goods and services intended for household consumption.

Border closures and restrictions on the movement of goods and people also adversely affected the local supply chain due to increased transport costs. Enhanced vehicle controls discouraged vendors from driving from the fields to further markets. As a result, supplies of staple foods such as fish, plantains, cocoyam and meat in the main markets of Douala and Yaoundé were at their minimum prices. Information circulating that Coronavirus could be treated with products lime, lemon, ginger, garlics and aloe vera hence conferring therapeutic virtue to such products attributed a significant price increase in these products as vendors took advantage of the situation by doubling or even tripling their prices. For example at Sandaga market in Douala, 3 limes were sold at 500FCFA and fruits like lemon were sold at about 300FCFA each. Seasonal changes as well can account for the increase in the prices of food stuffs like Irish potatoes and cabbage. Also, scarcity of food stuffs like plantain and cocoyams could likewise be accredited to the prevailing Anglophone crises affecting the country which has also contributed to the slowdown of economic activities in Douala.

\section{Discussion}

The COVID-19 pandemic is a health and human crisis threatening the food security and nutrition of millions of people across Cameroon. Despite the risk of undermining food systems already in difficulty and attributed to COVID 19, positive effects are underlined by the UNDP (March 2020) which notes the fall in the prices of export products. This could further favour and promote local products, especially the neglected food sector in favour of exported products. The tomato, of which a good part of the production was transported to the countries of the sub-region, including Gabon and Equatorial Guinea, whose customers set prices above 10,000 to ensure their supply made the difference. Subject to lower prices during the border closure period.

However, in view of the aspects taken into account by the authors in the definition of food security, the extension and promotion of local food cannot guarantee food security because it takes into account the availability, access, stability and availability. Use of all food resources without exception. Thus, the promotion of some to the detriment of others cannot ensure the lucidity of the food system. On the other hand, reasons such as excess production, whose market access limited the sale, favoured the collapse in the prices of certain essentially perishable products, such as the case of tomatoes, while the majority saw its cost increase by 10 to $50 \%$. Groundnuts were also the object of the increase (23\%), soyabeans 50\% [14]. Accentuated by the consequences of the pandemic, the poverty rate in large cities such as Douala and Yaoundé was already below average, the restrictive measures (confinement) with its impact on the economy contributed to it. The 2020 national GDP already registers a reduction of $3.2 \%$ with an inflation rate of $2.6 \%$ in the first period of the year; a record for at least 7 years with an increase of at least $5 \%$ in the price of rice [19]. In view of the socio-economic, security and food context before the virus and the damage caused by the latter on all aspects of life, a lasting solution is not feasible in the nearest future. In addition, the employment sector remains unpromising with almost $90 \%$ of the national population in the informal sector, including a considerable deterioration in living standards [10]. On the other hand, many people agree that the promotion of local production through food products would be favorable to food security, which would imply limiting imported products in order to reduce dependence on them. However, the cost of these products competes strongly with local food products.

\section{Conclusion}

Food insecurity is defined as the disruption of food intake or eating patterns because of lack of money and other resources [20]. Food insecurity does not necessarily cause hunger, but hunger is a possible outcome of food insecurity [21]. Food insecurity may be long term or temporary [22,23,24]. It may be influenced by a number of factors including income, high prices, employment, ethnicity, and disability. The risk for food insecurity increases when money to buy food is limited or not available $[20,25,26]$.

Unemployment can also negatively affect a household's food security status [27]. In Cameroon, increase in unemployment rates from $3.36 \%$ in 2018 to $3.43 \%$ in 2020 , coupled with the covid-19 pandemic among low-income populations made it more difficult to meet basic household food needs. In addition, children with unemployed parents experience higher rates of food insecurity than children with employed parents [2]. The cycle of food insecurity and chronic disease begins when an individual or family cannot afford enough nutritious food. The combination of stress and poor nutrition can make disease management even more challenging. Further, the time and money needed to respond to these health conditions strains the household budget, leaving little money for essential nutrition and medical care. This causes the cycle to continue, increasing the risk of worsening existing conditions. Many families experiencing 
food insecurity often have several, if not all compounding factors which makes maintaining good health extremely difficult. Forbes highlight major outcomes of food insecurity in adults and children

Adults are mostly faced with: micronutrient deficiencies, lower diet quality, poorer sleep outcomes, lower physical activity, smoking, lower overall health status, poorer physical health, poorer mental health, greater mental distress, lower cognitive function, depression, obesity, hyperlipidemia, hypertension, and diabetes.

Children's outcomes affected by food insecurity: increased developmental risk, lower physical function, lower psychosocial function, lower motor development, lower mental development, lower maternal attachment, hyperactivity, school absence, aggression and anxiety, internalizing disorders, externalizing disorders, mood disorders, behavior disorders, depression, asthma, mental health problems, behavioral problems, substance abuse problems, lack of concentration, difficulty getting along with peers, suspension from school, depression and thoughts of suicide.

In Cameroon, millions of people were already suffering from hunger and malnutrition before the virus hit and unless immediate action is taken, we could witness a national food emergency. In a long run, the combined effects of COVID19 itself, as well as corresponding mitigation measures and the emerging global recession could without large-scale coordinated action disrupt the functioning of food systems. Such disruptions can result in consequences for health and nutrition of a severity and scale unseen for more than half a century [28]. As many go hungry, there is a predominant concern that food shortages will lead to social discord. Cameroonians are shipwrecked, waiting for national strategies as citizens' loss their jobs at daily bases. It goes to show how hungry they are." To mitigate the impact of this crisis, the Cameroon government is fixing prices on food items, delivering free food and putting in place; plans to send money transfers to the poorest households.

\section{Compliance with ethical standards}

\section{Acknowledgments}

The authors thank all volunteers who participated in this study.

\section{Disclosure of conflict of interest}

The author declares no conflict of interest.

\section{References}

[1] Christophe Golay, "Crise et sécurité alimentaires: vers un nouvel ordre alimentaire mondial? », Africa: 50 years of independence - Review, Major development policy trends 2010 ; p. 215-232.

[2] Nord, M., \& Golla, A.M. “Does SNAP Decrease Food Insecurity? Untangling the Self-Selection Effect.” Washington, DC: U.S. Department of Agriculture, Economic Research Service, Economic Research Report 85, http://www.ers.usda. gov/Publications/ERR85/ERR85.pdf. Last accessed September2009; 5:2013.

[3] Carol Huss “The banyan tree: volume ii: bringing change - appropriate nutrition: its role in health", Health Library (C) 2020.

[4] Mkhawani, K., Motadi, S.A., Mabapa, N.S., Mbhenyane, X.G., \& Blaauw, R., "Effects of rising food prices on household food security on female headed households in Runnymede Village, Mopani District, South Africa" 2016; P.69-74

[5] DePolt, R.A., Moffitt, R.A. and Ribar. D.C., "Food Stamps, Temporary Assistance to Needy Families and food Hardships in Three American Cities". Pacific Economic Review 2009; 14 (4):445-473.

[6] Nord, M., \& Prell, M., 2011, "Food Security Improved Following the 2009 ARRA Increase in SNAP Benefits." Washington, DC: U.S. Department of Agriculture, Economic Research Service, Economic Research Report 116.

[7] Shaefer, H.L., \& Gutierrez, I., 2012, "The Effects of Participation in the Supplemental Nutrition Assistance Program on the Material Hardship of Low-Income Families with Children." Working Paper Series 11-18, National Poverty Center, http://npc.umich.edu/publications/u/2011-18-npc-working-paper-revised.pdf. Last accessed September 5, 2013.

[8] Yen, S.T., Andrews, M., Chen, Z. \& Eastwood, D.B., "Food Stamp Program Participation and Food Insecurity: An Instrumental Variables Approach.” American Journal of Agricultural Economics 2008; 90 (1):117-132.

[9] Joel, K. \& Bourne, J.R., 2009, “The Global Food Crisis: The End of Plenty” issue of National Geographic magazine. 
[10] NU, « Plan de réponse socioéconomique des nations unis contre le COVID » 2020; 19:80P

[11] IPES FOOD, « La crise dans le système alimentaire : symptômes, causes et solutions potentielles » 2020; 12P

[12] FAO \& UA, « Mesures de soutien des marches intérieurs durant l'épidémie de COVID 19 en Afrique. » 2020 ; P. 8.

[13] UA, BAD, « Intégrer la nutrition dans les plans d'action et de redressement en réponse à a COVID 19 ». Exposé de position sur le COVID 19. Initiative des dirigeants africains pour la nutrition 2020; (5P).

[14] Action contre la faim, « Impact de la COVID 19 sur la faim : Quand la pandémie en cache une autre ». 2020;30P.

[15] Stéphane Beaud \& Florence Weber, « Guide de l'enquête de terrain, Paris, La Découverte », $2010 ;$ p. 274.

[16] Mua Karl., 2020. Covid 19 : Tomatoe farmers comit suicide following poor sales

[17] Joyceline Ndouyou., 2020 (11h37), “Cameroon tribune. Impact économique du Covid-19: Comment relancer les secteure les plus touchés. "

[18] FEWS NET, Jui «Cameroon perspectives sur la sécurité alimentaire. Une quatrième saison consécutive de production inferieure à la moyenne dans les régions du Nord-Ouest et du Sud-Ouest » 2020; 13 P.

[19] GICAM 2020, "Rapport enquete covid-19 GICAM"

[20] Nord, M., Andrews, M., \& Carlson, S., 2007, "Household food security in the United States", Washington: USDA Economic Research Service; Available from: https://www.ers.usda.gov/webdocs/publications/46084/11227_err66.pdf?v=41056

[21] Carlson, S.J., Andrews, M.S. \& Bickel, G.W., "Measuring food insecurity and hunger in the United States: Development of a national benchmark measure and prevalence estimates", 1999; p.510-516.

[22] Jones, A., Ngure, F., Pelto, G. \& Young, S., “What are we assessing when we measure food security?” A compendium and review of current metrics. Adv Nutr. 2013; 4:481-505. doi: 10.3945/an.113.004119.

[23] FAO 2008, "An introduction to the basic concepts of food security" Rome: Food and Agriculture Organization of the United Nations; Available from: http://www.fao.org/docrep/013/al936e/al936e00.pdf [PDF - 83 KB] External Web Site Policy

[24] Nord, M., Andrews, M. \& Winicki, J. "Frequency and duration of food insecurity and hunger in US households", 2002; p. 194-201.

[25] Sharkey, J.R., Johnson, C.M. \& Dean, W.R., "Relationship of household food insecurity to health-related quality of life in a large sample of rural and urban women." Women Health. 2011; 51(5):442-60.

[26] Seefeldt, K.S., Castelli, T.,2009, "Low-income women's experiences with food programs, food spending, and foodrelated hardships", Washington: USDA Economic Research Service; Available from: https://naldc.nal.usda.gov/download/35894

[27] Nord, M. "Characteristics of low-income households with very low food security": An analysis of the USDA GPRA food security indicator. USDA-ERS Economic Information Bulletin No. 25. 2007

[28] European Commission, 2020 "Knowledge for policy, Policy Brief: The Impact of COVID-19 on Food Security and Nutrition" 